\title{
MEMOIR
}

\section{SIR GEORGE EPPS}

ГнЕ death of Sir George Epps will have affected actuaries in many countries with an unusual feeling of personal loss. For Epps was more than a good actuary, ulfilling with a high sense of public duty the responsibilities of a senior position $\mathrm{n}$ the Government service; he was a 'character' of subtle charm, and those who nnew him will cherish many endearing recollections of their contacts with him.

Epps started life with many advantages; his very name, George Selby Washington Epps, struck the imagination. Born 26 February 1885 , the son of Dr Washington Epps, a physician who was then practising in Great Russell Jtreet, he was a member of a well-known homoeopathic family. His mother was a sister of Alma Tadema the painter, and the family was also connected with the Josses, who themselves were linked, by marriage, with William Morgan. It is tot surprising, therefore, that Epps showed an appreciative interest in literary and artistic things.

From a preparatory school at Hampstead hewent on to Highgate School in 1899 and, at the end of 1903 , was awarded an entrance scholarship in mathematics at Emmanuel College, Cambridge. He graduated B.A. with the degree of Senior Optime in the Mathematical Tripos of 1907.

G. F. Hardy was a patient of Epps's father and the two families were friendly perhaps it was this influence that made Epps decide, rather against his family's wishes, to become an actuary. Through Hardy's introduction he entered, in 1907, the actuarial department of the English and Scottish Law Life, which was then in John Spencer's charge, and at the same time he joined the famous Part II Classes then being conducted at the Institute of Actuaries by Elderton (later by Macnaghten). At the English and Scottish, somewhat surprisingly, he is said to have thrived on sorting cards and other routine work of a lowly order. No doubt this discipline was valuable for one of his disposition, and it was all to the good that he had a few years of office routine before joining Sir Alfred Watson in what was later to become the Government Actuary's Department-for Epps had very little to do with routine work once he had joined Watson's staff.

In I9I I and rgr2 Watson, who had heen appointed Chief Actuary to the National Health Insurance Joint Committee under the new Act of I9II, was looking for young actuaries to join his staff. The name of Epps had been suggested by Spencer (one of Watson's oldest friends), and in February I9 2 he joined the Department with a view to acting as Secretary of the Actuarial Advisory Committee set up to frame the financial arrangements of the new scheme. The Committee consisted of G. F. Hardy, G. Douglas (President of the Faculty), D. C. Fraser, G. J. Lidstone and Watson. It must have been stimulating company in which to work. From that time onwards he was working directly for Watson, in very close touch with him, and Watson came to appreciate his services and to rely on him to an increasing extent. In the earlier days his official work was almost wholly concerned with National Health Insurance financea subject on which he became second only to Watson himself as the foremost expert-and although, later, he occupied himself with many other matters, Health Insurance retained for him a special interest.

On qualifying as a Fellow of the Institute in r913 Epps had been appointed an Assistant Actuary in the Department, and his Secretaryship of the Actuarial 
Advisory Committee (I912-15) was followed by appointment as Secretary-in its later stages-to the Departmental Committee on Approved Society Finance and Administration under the Chairmanship of Sir Gerald Ryan. After the Ryan Committee reported in 1916, Epps had a very strenuous and important period of work in the preparation of the substantially altered scheme of National Health Insurance which was embodied in the Act of r9r8. It is unnecessary to enumerate all the committees on National Health Insurance affairs on which he served, but one is perhaps worthy of mention, namely, the Departmental Committee on the Application of the Government of Ireland Act, 1920, to National Health Insurance. Watson was the Chairman of this Committee and Epps its Secretary, and Epps was largely responsible for the carrying through of the financial adjustments to National Health Insurance arising out of the Partition. His work was recognized by the award of a C.B.E. in 1926 .

Meanwhile, Epps had been giving attention to the subject of superannuation, more especially in relation to the public services, and in 1921 he submitted to the Institute a paper entitled Superannuation Funds: Notes on some Post-War Problems, together with an account of a Pensioner's Mortality Experience (Civil Service Pensioners, 1904-1914). This paper, which examined the effects on superannuation finance of post-war changes in salary levels, rates of interest, income tax and so on, was of great value at the time and was awarded a prize from the Institute's Joint Prize Fund. It contained some ingenious technical ideas as well as sound and thoughtful comment on the problems dealt with-and it will repay reading today. It was to be Epps's only contribution to the literature of the Institute, though he took part occasionally in discussions on papers concerned with superannuation, friendly societies and social insurance.

In September 1926, Alfred Henry, the Deputy Government Actuary, died suddenly and Epps was, on Watson's recommendation, appointed to succeed him. Epps's official work naturally widened in scope, his responsibilities increased, and in I93 $\mathrm{I}$ he received the honour of a C.B. Among the many departmental and other committees on which he served may be mentioned the Probation Officers' Superannuation Committee (1926), the Selby-Bigge Committee on Superannuation of Local Government Employees (1927), the Cassel Committee on Compulsory Insurance (1937) and the Committee on Police Widows' Pensions (194I), which published reports in the years shown.

Watson's temperament and health, as well as his preoccupation with his official duties, made him reluctant to be away from his office except during the usual summer vacation; thus Epps made several visits abroad, some on League of Nations or International Labour Organization business, some (in Watson's stead) as the British Government's representative to International Actuarial Congresses. On these occasions he was undoubtedly a good ambassador, one whom foreign actuaries and officials found it easy to meet, and whom they did not readily forget; he himself enjoyed these 'foreign relations' and took great care with them.

On the death of Watson in May 1936 Epps was appointed to succeed him as Government Actuary. The circumstances were difficult, for the extinction of the positive and dominating personality of Watson inevitably changed the relationship of the Department to other Government departments, and it was not possible to 'carry on as before'. 'The diffident personality of Epps was not ideally suited to meeting this situation, but in his quiet way he tackled one problem after another and maintained unimpaired the high professional reputation of the Department. The War of 1939 came all too quickly and presented new 


\section{Memoir}

problems for a Department much of whose work was likely to disappear under war conditions. Epps was able, whilst lending the majority of his staff for service in various War Departments, to retain with him in the Government Actuary's Department a nucleus staff for which, in the event, ample if sometimes unaccustomed work was found. Moreover, in I94I Epps became heavily engaged in the work of the Beveridge Committee on Social Insurance and Allied Services, both as a member of the Committee and as its actuarial adviser. In these duties he was able to bring unrivalled experience and ability to the assistance of the Committee, and in due course a report by the Government Actuary on the finance of the 'Beveridge Scheme' formed an important appendix to Sir William Beveridge's report which was published in 1942. In that year, also, Epps was knighted and became a K.B.E.

Epps's health had always been rather delicate, and he showed evident signs of strain from time to time due to the pressure of the urgent and difficult work which so often came his way. The War bore hardly on one of his temperament, and although he struggled hard to see it through without retiring from duty he was forced at last, on the orders of his doctor, to ask to be relieved of his appointment. He retired on 30 November 1944, three months before reaching the age of 60 , and went to live on a farm among the hills of Somerset. There, with his wife and a daughter (the farmer), he continued to enjoy many of the very varied interests which had made life worth while for him and to lead-for an invalida fairly active existence in spite of some bad setbacks. So it was until, on 8 February $195 \mathrm{I}$, he died suddenly and peacefully.

The combination of heavy official duties and delicate health restricted the extent of Epps's other activities and, in particular, his services to the Institute. But he served for many years on the Council and he was an Hon. Secretary in 1928-30 and a Vice-president in 1930-32. It was behind the scenes, however, that his best work was done for the Institute-and in other spheres-for he was invaluable as a counsellor whose advice (if he could be persuaded to give it) was always worth having, never superficial, often exhibiting a new and unexpected angle. He took a keen interest also in the affairs of the Royal Statistical Society, served on its Council, was a Vice-President of the Society in 1941-43, and an active member of several committees set up to deal with special subjects. In earlier days he had played an active part in the development of the Institute of Public Administration.

George Epps was a complex person. To the writer it has always seemed that he might have been more at home in the eighteenth century as a country squire who was at the same time an amateur of the arts. The short rotund figure, palefaced and fair-haired - with the old-fashioned metal-framed spectacles which he never discarded, the mole-skin waistcoat which was his pride for a long time, the rather careless bow-tie which he gave up in later years-concealed an acute intelligence. He had a cool appraising intellect which seemed to work rather by perception than by analysis. He rarely made the obvious remark; looking, or feeling, round all the facets of a situation, his speech tended to be allusive and elliptical. Thus conversation with him was sometimes like a series of knight's moves in chess; for those who could react as quickly, and in sympathy, it was illuminating; for others it was rather baffling. His habit of looking all round a problem, and his capacity to listen patiently and sympathetically to other points of view, had their drawbacks; they were handicaps to action. But they were a part of the man, consistent with that humane outlook and sly humour, that kindliness in action as in speech, that linger so gratefully in the memory.

G. H. M. 